
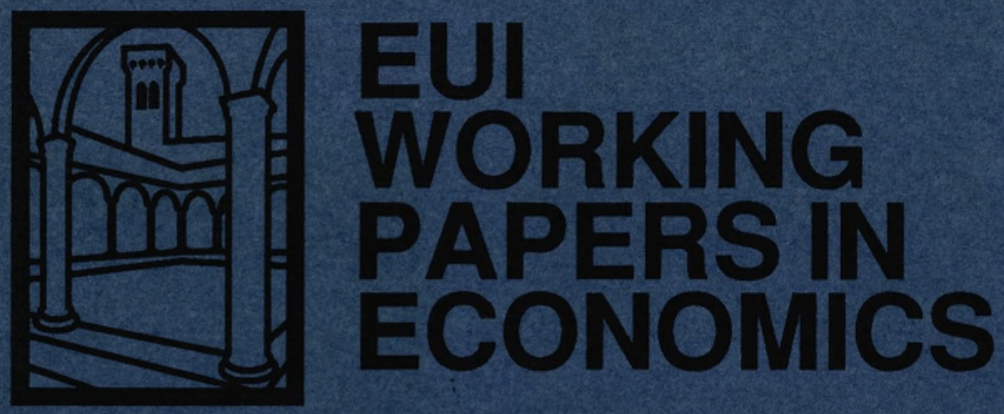

Profits, Risk and Uncertainty in

Foreign Exchange Markets

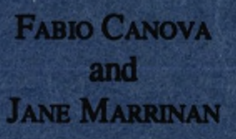

EUI Working Paper ECO No. $92 / 73$ 
European University Library

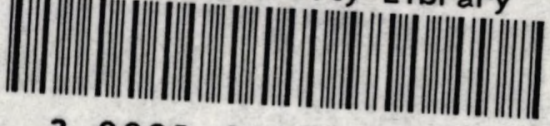

30001001348319

Please note

As from January 1990 the EUI Working Paper Series is divided into six sub-series, each sub-series is numbered individually (e.g. EUI Working Paper LA W No. 90/1). 


\section{EUROPEAN UNIVERSITY INSTITUTE, FLORENCE}

ECONOMICS DEPARTMENT

EUI Working Paper ECO No. 92/73

Profits, Risk and Uncertainty in

Foreign Exchange Markets

FABIO CANOVA

and

JANE MARRINAN

BADIA FIESOLANA, SAN DOMENICO (FI) 
All rights reserved.

No part of this paper may be reproduced in any form without permission of the authors.

(C) Fabio Canova and Jane Marrinan

Printed in Italy in May 1992

European University Institute

Badia Fiesolana

I-50016 San Domenico (FI)

Italy 


\title{
Profits, Risk and Uncertainty in Foreign Exchange Markets
}

\author{
Fabio Canova * \\ Department of Economics, Brown University \\ Providence, RI 02912, USA \\ and \\ Department of Economics, European University Institute \\ I-50010, San Domenico di Fiesole (FI), Italy \\ and \\ Jane Marrinan \\ Department of Economics, Boston College \\ Chestnut Hill, Ma 02167, USA \\ and \\ Department of Economics, European University Institute \\ I-50010, San Domenico di Fiesole (FI), Italy \\ This Revision, November, 1991
}

\begin{abstract}
This paper examines the time series properties of nominal profits from speculation in dollar denominated forward contracts using a representative agent cash-in-advance model, modified to allow for time variation in the conditional variances of the exogenous processes. The model is simulated by estimating exogenous processes from the data and the remaining free parameters with a simulated method of moments technique. Simulated expected profits closely replicate the statistical behavior of observed nominal profits on the U.S. dollar in the floating regime period. As in the actual data simulated forward rates display biasedness in predicting simulated future spot rates.
\end{abstract}

JEL Classification No.: 212, 431

*We would like to thank an anonymous referee and the editors of this journal, David Backus, Charles Engel, Jeffrey Frankel, Mark Gertier, Craig Hakkio, Takatoshi Ito, Fredrick Mishkin, Masao Ogaki, Adrian Pagan, Mark Salmon; the participants of the NBER summer workshop on Capital Market Integration; of the Second CEPR Macro workshop, Madrid; of the AFFI meeting, Louvain; of the EFA meeting, Rotterdam; of the AFA meeting, New Orleans and of the seminars at Brown, Johns Hopkins, NYU, Rochester, Virginia and Yale for comments and suggestions. 


\section{Introduction}

A large body of empirical work indicates that throughout the 1980's nominal profits from speculation in forward contracts on the U.S. dollar displayed predictable and highly volatile fluctuations (see e.g. Frankel and Meese (1987) and Hodrick (1987)). Whether this behavior reflected movements in expected profits arising from traders' assessment of future fundamentals or was simply the result of forecast errors is still unresolved. A central issue in the debate has been determining whether changes in the perceived risk of engaging in a forward contract can account for the fluctuations in observed profits.

Frankel (1986) uses a mean-variance optimization framework to derive theoretical restrictions on the size of the risk premium in foreign exchange markets ${ }^{1}$. Since these theoretical bounds imply small and constant expected profits, he finds it difficult to attribute the time series properties of realized nominal profits on the dollar experienced in the 80 's to risk (see also Giovannini and Jorion (1988)). Instead, based on survey data measuring expectations of future spot rates, Frankel and Froot (1987) and Froot and Frankel (1989) provide empirical support for the view that the statistical properties of realized nominal profits on the dollar are more closely related to those of the forecast error than the risk premium.

These results led some authors (see e.g., Lewis (1989), Kaminsky (1989)) to construct theoretical models where the risk premium is negligible and the properties of observed profits are due entirely to expectations of unrealized policy regime shifts, which generate volatile and serially correlated forecast errors.

Another branch of literature (see e.g., Hodrick and Srivastava (1984) Cumby (1988), Flood (1988), Macklem (1991) and others) has examined theoretical models where the risk premium can vary over time and thus, in principle, account for the statistical properties of observed profits. This literature, which is based on the intertemporal consumption based asset pricing model (ICCAPM) with time separable preferences, has concluded that the framework is unable to replicate the variability and serial correlation properties of profits under a relatively wide range of parameterizations. This result is consistent with the evidence in other asset

\footnotetext{
${ }^{1}$ The expected component of profits, often interpreted as a risk premium, is actually the sum of a risk premium and a convexity term arising from Jensen's inequality. It is, however, common to ignore the convexity term on the grounds that it is small (see e.g. McCulloch (1975), Frenkel and Razin (1980)) and attribute the statistical features of expected profits to a time varying risk premium.
} 
markets (see e.g. Merha and Prescott (1985), Backus, Gregory and Zin (1989), Giovannini and Labadie (1989)). In general, the paradigm fails to reconcile the small variability in aggregate consumption with the relatively large, volatile and serially correlated profits in excess of the risk free rate observed for many risky assets. In response to these failures, many authors have recently modified the standard ICCAPM to account for habit persistence. For foreign exchange markets Backus, Gregory and Telmer (1990) found the modification helpful in reproducing the variability of expected profits from forward speculation.

In a standard international ICCAPM, the expected component of profits depends on the conditional covariance between the nominal intertemporal marginal rate of substitution and the change in the nominal exchange rate. The conditional variances of these two quantities, typically assumed to be constant, may affect the level but do not account for the time series properties of expected profits. This paper explicitly recognizes that the conditional volatility of fundamentals may be an important determinant of expected profits. We attempt to determine whether variation over time in the variability of fundamentals of the economy is useful in providing a quantitative account of the time series behavior of observed profits.

In this exercise we employ a standard two country, two good, cash-in-advance (CIA) model. Exogenous stochastic processes governing the behavior of output, monetary and fiscal policies determine the endogenous variables of the model. Following Hodrick (1989), we introduce distributional assumptions that imply that the population properties of equilibrium expected profits from forward speculation depend on the time series features of the conditional moments of the exogenous processes. In the closed form solution we derive, the theoretical time series properties of expected profits depend on three factors: the parameter of risk aversion, the share of foreign goods in household consumption and the conditional and unconditional variances of the money supplies and government expenditure shares.

The model is simulated by estimating exogenous fundamental processes from actual data and choosing the remaining parameters using a simulated method of moments approach (see Lee and Ingram (1990), Duffie and Singleton (1990)). We use this approach, as opposed to more standard estimation techniques, because it uses the complete representation of the stochastic equilibrium model. Also, it is preferable to simple calibration exercises since it allows us to both formally select free parameters and undertake sensitivity analysis by exam- 
ining the statistical properties of the time series generated by the model under a wide variety of parameterizations.

The simulations demonstrate that the time series for expected profits display statistical properties which are similar to those of the cross sectional average nominal profits on the US dollar in five foreign exchange markets in the floating regime era for two holding maturities. We find that fluctuations in the conditional variability of government consumption is largely responsible for the variability and serial correlation properties of the simulated expected profits series. We also find that the properties of the consumption risk premium of the model, that is, the component of expected profits arising solely from risk averse behavior, can be quite different from the realized nominal profit series. This suggests that, although it is common to attribute movements in nominal profits to a time varying risk premium, the error in doing so may be large (see also Engel, 1990 for this point). Finally, we show that the simulated forward rate is a biased predictor of the simulated future spot rate. This feature of the actual data has been extremely puzzling from the point of view of the simple expectational hypothesis. Here biasedness occurs because the forward rate forecast error in predicting future spot rates is neither homoschedastic nor uncorrelated with the available information set. When spot and forward rates are generated by heteroschedastic driving processes, regression tests of efficiency miss the dynamics of the data and provide erroneous conclusions regarding efficiency.

The paper is organized as follows. The next section analyzes the statistical properties of realized nominal profits on the dollar in five foreign exchange markets. Section 3 presents the theoretical framework of analysis and identifies the determinants of expected profits. Section 4 describes the estimation of exogenous processes from actual data, introduces the simulated method of moments technique and estimates the free parameters of the model. Section 5 contains a discussion of the results and a sensitivity analysis. Section 6 compares the model's implications for consumption, spot and forward rates with the actual data. Conclusions appear in section 7 . 


\section{The Properties of Nominal Profits from Forward Specula- tion}

This section examines the statistical properties of nominal profits on the dollar in five different exchange markets. The markets considered are German Mark/US dollar, French Franc/US dollar, UK Pound/US dollar, Japanese Yen/US dollar and Swiss Franc/US dollar (or Canadian dollar/US dollar). The data employed are monthly observations of the closing value on the last business day of the month at the London market. Let $S_{t}$ be the foreign currency price of a US dollar for immediate delivery and $F_{t, k}$ be the foreign currency price of a $k$ month contract for delivery of a dollar at $t+k$. Then, the (approximate) annualized percentage realized nominal profits in market $i$ is computed as $R P_{t, k}^{i}=(1.200 / k) *\left[\ln \left(S_{t+k}^{i}\right)-\ln \left(F_{t, k}^{i}\right)\right]$. We present results for $k=3$ for the sample period 1975,1-1991,9 and for $k=1$ for the sample period 1974,6-1986,10.

There are two reasons for selecting these two holding maturities. We chose $k=1$ to maintain comparability with existing work (see e.g. Backus, Gregory and Telmer (1990) and Macklem (1991)). We would like to know if our modification of the basic model helps to understand their pattern of results. In addition, we select a longer holding period because there is some evidence (see e.g. Lewis (1991)) that the holding period matters for both the statistical properties of profits and for tests of the ICCAP model. For example, while practically all the literature using a weekly or monthly holding period rejects the model (see e.g. Hodrick and Srivastava (1984)), for $k=3$ Campbell and Clarida (1987) fail to reject it. Table 1, columns 1-5 report the statistical properties of $R P_{t, 3}^{i}$ in the first five exchange markets while Table 2, columns 1-5 report those of $R P_{t, 1}^{i}$. For one month profits we use the Canadian dollar/US dollar market in place of the Swiss franc/US dollar market to maintain the same set of currencies used by Backus, Gregory and Telmer (1990).

Several features of $R P_{t, 3}^{i}$ deserve comment. First, the unconditional means of nominal profits for all five currencies are small and insignificantly different from zero. Second, the estimated values for the third and fourth unconditional moments suggest that the data does not grossly deviate from normality except perhaps in the case of the $\mathcal{L} / \$$ exchange market. Third, in all markets the unconditional varial,ility is large relative to the unconditional mean 
and the serial correlation properties of nominal profits on the dollar are nonnegligible. Because the 3 month holding period exceeds the sampling frequency of the data, one should expect some serial correlation to appear even though the true profit series is not predictable using time $t$ information. However, even if MA components of order 2 may exist, the third and forth AR coefficients should equal zero under the null of no serial correlation. We use Cumby and Huizinga's (1990) test to examine the significance of these AR coefficients when MA(2) components are present in the data and find weak evidence against the null hypothesis of no serial correlation.

An examination of the properties of the conditional distribution of $R P_{t, 3}^{i}$ suggests very little evidence of nonlinearities in the first two moments of the distribution. A test for ARCH in the residuals of a six-lag autoregression of each series does not reject the assumption of conditional homoschedasticity in all markets. Similarly, the Breush and Pagan (1979) and White (1980) tests do not reject the null hypothesis of conditional homoschedasticity. The lack of heteroschedasticity in the series contrasts with evidence for weekly and daily data reported in Baillie and Bollerslev (1990). One way to reconcile the results is to invoke time aggregation along the lines of Diebold (1988). Finally, the Brock and Dechert (1988) test for nonlinearities in the recursive residuals $\hat{\epsilon}_{t}=\left(y_{t}-\hat{a}_{t}(L) y_{t-1}\right) / \hat{\sigma}_{t}$, where $\hat{a}_{t}(L) y_{t-1}$ and $\hat{\sigma}_{t}$ are estimates at $t$ of the conditional mean and the conditional standard error of nominal profits in each market, do not reject the hypothesis that $\hat{\epsilon}_{t}$ is a white noise in all markets.

Since the results are fairly homogeneous across markets, we construct the cross sectional average nominal profits on the dollar over the five different exchange markets. This series corresponds to the profits obtainable at each $t$ by a US trader who purchases an equally weighted portfolio of forward contracts of the five currencies and sells the contracts at maturity. The statistical features of this cross sectional average are presented in table 1 , column 6 and in figure 1, panel A, which plots the series and its estimated MA representation. None of the features previously described is altered. The cross sectional average profits on the dollar has a zero unconditional mean. The unconditional variance of the series is smaller than the unconditional variances of nominal profits in individual markets, but is still large relative to its unconditional mean. No skewness or excess kurtosis in the unconditional distribution of the series is generated by the averaging procedure. The estimated MA representation indicates 
that an innovation to the process displays little persistence over time and decays at the rate of an AR(1). Finally, there is no evidence of nonlinearities in the conditional moments of the series. The conditional mean is well approximated by a linear function, while the conditional variance is roughly constant.

The statistics for 1 month profits display similar characteristics. The most striking differences are the fifty percent increase in the variability of each profit series and a marked tendency of excess kurtosis to appear in all but the $£ / \$$ market. The cross sectional average profit series (plotted in figure 2, panel A, with the corresponding MA representation) again shows substantial similarities with individual series.

We view these two cross sectional average nominal profit series as representative of the conditions existing in foreign exchange markets during the floating regime era and compare their statistical properties with those of expected profits simulated by the model.

\section{The Theoretical Framework of Analysis}

The theoretical framework we employ is a version of the cash-in-advance monetary model developed by Lucas (1982) and modified by Hodrick (1989). Since the model is well known in the literature, we only briefly describe its features and proceed directly to the computation of the equilibrium values of the variables of interest.

The economy is characterized by 2 countries: The US and the rest of the world. Every period, each country $i$ is endowed with $Y_{i t}, i=1,2$ units of a nonstorable consumption good. There are 2 governments which consume $G_{i t}$ units of their own country's good. To finance these consumption requirements each government issues a country specific money, $M_{i t}$, collects real lump sum taxes, $T_{i t}$, levied equally on agents from both countries, and issues debt to finance any purchases in excess of money creation and tax collections. This debt is in the form of state contingent nominal bonds of maturity $k, k=1,2, \ldots, K$, denominated in their own country's currency. Endowments, government consumption requirements and money supplies are exogenous and follow a first order Markov process with a stationary and ergodic transition function. 
The countries are each populated by a representative household maximizing a time separable utility function defined over the two goods. Households are subject to both a wealth constraint and a liquidity constraint which compels them to purchase goods with cash. The timing of the model follows Lucas with asset markets open first and goods markets following. At the beginning of each period the consumer enters the asset market and decides how to allocate her wealth among the productive assets of the 2 countries, currencies, and the state contingent nominal bonds issued by the 2 governments. After the asset market closes, the consumer enters the goods market and makes her consumption purchases with previously accumulated currency.

Equilibrium requires that households optimize and all markets clear. Since capital markets are complete, this permits an unconstrained Pareto optimal allocation of the time-state contingent nominal bonds.

Let $e^{-r_{i t, k}(v)}$ denote the discount price at $t$ of a bond paying 1 unit of currency $i$ at time $t+k$, if event $v$ occurs and $r_{i t, k}(v)$ denote the associated continuously compounded interest rate.

In equilibrium nominal interest rates reflect optimal consumption-saving decisions by equating bond prices to individuals' expected marginal rate of substitution of future nominal expenditure for current nominal expenditure, i.e.,

$$
e^{-r_{i t, k}}=\frac{\beta^{k} E_{t} P_{i t} U_{i t+k}\left(c_{1 t+k}, c_{2 t+k}\right)}{P_{i t+k} U_{i t}\left(c_{1 t}, c_{2 t}\right)}
$$

Because all uncertainty is resolved prior to the household's money holding decisions, they hold just enough currency to finance their current consumption purchases. This implies that the quantity theory holds so that $P_{i t}=\frac{M_{i t}}{Y_{i t}}$ and

$$
e^{-r_{i t, k}}=\frac{\beta^{k} E_{t} Y_{i t+k}\left(M_{i t+k}\right)^{-1} U_{i t+k}}{Y_{i t}\left(M_{i t}\right)^{-1} U_{i t}}
$$

Hodrick, Kocherlakota, Lucas (1991) show that when a one country version of the above model is calibrated to the US economy the cash-in-advance constraint almost always binds. Bekaert (1991) shows that the same occurs in a two country setting. Therefore, there appears to be little practical gain in specifying models with more complicated nonbinding constraints (as in Hodrick (1989)). 
In equilibrium, the nominal spot rate is equal to the marginal rate of substitution of domestic currency for foreign currency:

$$
S_{t}=\frac{U_{1 t} p_{2 t}}{U_{2 t} p_{1 t}}=\frac{Y_{1 t}\left(M_{1 t}\right)^{-1} U_{1 t}}{Y_{2 t}\left(M_{2 t}\right)^{-1} U_{2 t}}
$$

Therefore, the $k$-period ahead conditional future log spot rate is given by:

$$
E_{t} \ln S_{t+k}=E_{t} \ln \left[\frac{Y_{1 t+k}\left(M_{1 t+k}\right)^{-1} U_{1 t+k}}{Y_{2 t+k}\left(M_{2 t+k}\right)^{-1} U_{2 t+k}}\right]
$$

Finally, from (2) and (3) and using covered interest parity we can price a $k$-period forward rate as:

$$
F_{t, k}=S_{t} e^{r_{2 t, k}-r_{1 t, k}}=\frac{E_{t} Y_{1 t+k}\left(M_{1 t+k}\right)^{-1} U_{1 t+k}}{E_{t} Y_{2 t+k}\left(M_{2 t+k}\right)^{-1} U_{2 t+k}}
$$

If we let the time interval of the model be a month, the approximate annualized percentage expected nominal profits on the $\$$, defined as $E P_{t, k}=\frac{1200}{k} *\left(E_{t} \ln \left(S_{t+k}\right)-\ln \left(F_{t, k}\right)\right)$, can be computed from (4) and (5) as

$$
E P_{t, k}=\frac{1200}{k} *\left(E_{t} \ln \left\{\left[\frac{Y_{1 t+k}\left(M_{1 t+k}\right)^{-1} U_{1 t+k}}{Y_{2 t+k}\left(M_{2 t+k}\right)^{-1} U_{2 t+k}}\right]\right\}-\ln \left\{\frac{E_{t}\left[Y_{1 t+k}\left(M_{1 t+k}\right)^{-1} U_{1 t+k}\right]}{E_{t}\left[Y_{2 t+k}\left(M_{2 t+k}\right)^{-1} U_{2 t+k}\right]}\right\}\right)
$$

Inspection of (6) reveals some interesting features. First, as Backus and Gregory (1989), Sibert (1989) and others have recently pointed out, expected nominal profits from forward speculation will be different from zero even when agents are risk neutral. Note, however, that expected profits will be zero when all the exogenous processes are constant or deterministically fluctuating. Second, $E P_{t, k}$ depends on expectations about future outputs, future money supplies and future terms of trade. Since in equilibrium expectations about future terms of trade depend on expectations about future government purchases of goods, both supply and demand factors affect expected profits. Finally, uncertainty about regime shifts or regime persistence influence the expectation formation and therefore the statistical properties of expected profits. In other words, if a "peso problem" exists, it will appear in (6) as well as in the forecast error in predicting future spot rates.

To obtain a closed form expression for $E P_{l, k}$ the instantaneous utility function is specialized to be of a constant relative risk aversion (CRRA) type as:

$$
U\left(c_{1 t}, c_{2 t}\right)=\frac{\left(c_{1 t}^{\delta} c_{2 t}^{1-\delta}\right)^{1-\gamma}}{1-\gamma}
$$


where $\delta$ is the share of domestic goods in total consumption expenditure and $\gamma$ is the parameter of risk aversion. The CRRA specification has attractive features: it is easy to manipulate and allows the construction of a risk neutral utility function in multigood settings (see Engel (1990)), a feature we will use in our simulations. Its major drawback is that it restricts the spot rate to depend only on monetary factors (see e.g. Bekaert (1991)).

Let $\Phi_{i t}$ be the proportion of government $i$ 's consumption in total output of good $i$ at time $t$. In a pooled equilibrium $c_{i t}=.5\left(Y_{i t}-G_{i t}\right)=.5 Y_{i t}\left(1-\Phi_{i t}\right)$. Evaluating the marginal utilities in (6) at these equilibrium consumption levels gives an expression for expected profits entirely in terms of the distributions of the exogenous variables. The complete solution requires substituting in the specific processes governing the exogenous variables.

We assume that all exogenous processes are conditionally independent. The processes for the growth rates of outputs and money supplies are assumed to be conditionally lognormally distributed. The processes governing the fraction of each country's output purchased by the governments is assumed to be conditionally uniformly distributed. Let $z_{t}=$ $\left[\Delta \ln \left(Y_{1 t}\right), \Delta \ln \left(Y_{2 t}\right), \Delta \ln \left(M_{1 t}\right), \Delta \ln \left(M_{2 t}\right), \Phi_{1 t}, \Phi_{2 t}\right]$ where $\Delta \ln \left(x_{t}\right)=\ln \left(x_{t}\right)-\ln \left(x_{t-1}\right)$. All six processes are assumed to follow a first order autoregression

$$
z_{j t}=A_{0 j}+A_{1 j} z_{j t-1}+\epsilon_{j t} \quad j=1, \ldots, 6
$$

and their conditional variances are assumed to follow a $\operatorname{GARCH}(1,1)$ process:

$$
\sigma_{j t}^{2}=a_{0 j}+a_{1 j} \sigma_{j t-1}^{2}+a_{2 j} \epsilon_{j t-1}^{2}, \quad j=1, \ldots, 6
$$

With these assumptions (6) reduces to:

$$
\begin{aligned}
E P_{t, k} & =\frac{1200}{k}\left\{-\mathcal{G}_{5 t}-\mathcal{G}_{6 t}-0.5 \sigma_{4 t, k}^{2}+0.5 \sigma_{3 t, k}^{2}-\ln [1+\delta(1-\gamma)]+\ln [\delta(1-\gamma)]\right. \\
& +\ln [(1-\delta)(1-\gamma)]-\ln [1+(1-\delta)(1-\gamma)]\}
\end{aligned}
$$

where $\mathcal{G}_{5 t}$ and $\mathcal{G}_{6 t}$ are given in the appendix and involve the risk aversion parameter, the share of domestic goods in total consumption and the conditional variances of government consumption shares. While the distributional assumptions we make allow us to derive an exact closed form solution, one could alternatively follow Breeden (1986) and take a second order Taylor expansion of (6) around $z_{t}$. Equation (10) would still hold, apart from an approximation error reflecting conditional covariances and higher order terms. 
For the version of the model considered here $E P_{t, k}$ depends on the risk aversion parameter, on the share of domestic good in total private consumption and on the conditional variances of both countries money supplies and governments' consumption shares. Therefore, in the closed form solution we derived, expected profits have a peculiar factor structure with the conditional variances of the exogenous processes accounting for their time series properties.

It easy to verify that (i) the unconditional variance of the exogenous variables influences the average size of $E P_{t, k}$, (ii) deviations of their conditional variances relative to the unconditional variances affect the unconditional variance of $E P_{t, k}$, (iii) the parameter of risk aversion $\gamma$ affects both the unconditional mean and unconditional variability of $E P_{t, k}$, (iv) the serial correlation properties of the conditional variances of the exogenous processes are entirely responsible for the serial correlation properties of expected profits.

To generate time series for expected profits from (10) it is necessary to select values for 14 parameters $\left(\gamma, \delta, a_{03}, a_{13}, a_{23}, a_{04}, a_{14}, a_{24}, a_{05}, a_{15}, a_{25}, a_{06}, a_{16}, a_{26}\right)$. To provide discipline in the simulation, we estimate as many parameters as possible from observed data. Since the model describes the US economy vs. the rest of the world (ROW), we estimate the conditional variances of the two money processes from comparable US and ROW monetary aggregates. This pins down 6 parameters $\left(a_{03}, a_{13}, a_{23}, a_{04}, a_{14}, a_{24}\right)$. Also, because of the symmetry of the model, and in agreement with previous simulation studies (see Engel (1990)), we fix $\delta=0.5^{2}$.

Since monthly data on the share of government spending in total output is not available, we choose the parameters regulating the variances of government expenditure shares and the risk aversion parameter $\gamma$ by simulation. That is, we choose these parameters to formally match statistics of the simulated and of the actual data. Since quarterly data on government spending is available, we further impose the consistency requirement that if the simulated series for government expenditure shares are aggregated at a quarterly frequency, they must have the same unconditional means and variances as the actual data. This restriction pins down the values of $a_{05}$ and $a_{06}$ and imposes cross equation restrictions which effectively limit the range of parameter values allowed in the simulations.

\footnotetext{
${ }^{2}$ We conducted experiments varying $\delta$ in the range $[0.5,1.0]$ with no appreciable change in the results.
} 


\section{Estimation and Specification Tests for the Exogenous Vari- ables}

The money supply data for the US and the rest of the world is obtained from IFS tapes. The measure for the world money supply is constructed by averaging comparable M1 aggregates for UK, West Germany and Japan. All these series span the 1975,1-1990,12 period.

Table 3 contains diagnostic tests for our chosen AR(1)-GARCH(1,1) specification for the money supply processes. In each case a first order univariate autoregression on the difference of the $\log$ of the series was used to construct residuals. For each residual series we apply the Cumby and Huizinga test for serial correlation, the ARCH, Breush and Pagan and White tests for conditional heteroschedasticity and the Brock and Dechert test for nonlinearities to the normalized residuals. The table also reports cross correlations of the residuals.

The results support our time series specification. First, none of the cross correlations of the residuals of the two series were found to be significantly different from zero, providing evidence in favour of univariate specifications. No serial correlation appears in the residuals but there is evidence of conditional heteroschedasticity in both series. In general we find a smooth decay of the regression coefficient of the squared residuals, suggesting that a $\operatorname{GARCH}(1,1)$ is a reasonable characterization of the conditional variances. Finally, the Brock and Dechert test does not reject the hypothesis that the normalized residuals of our estimated processes are white noises. Table 4 reports the results of estimating an $\operatorname{AR}(1)-\operatorname{GARCH}(1,1)$ specification for the two series.

To estimate the remaining five parameters of the model we employ the "estimation by simulation" technique proposed by Lee and Ingram (1990). The method computes optimal parameter estimates by minimizing the distance between a vector of statistics of the actual and the simulated data in the metric given by the covariance matrix of the statistics.

Let $x_{t}, t=1, \ldots T$ be a vector of time series of actual data and let $y_{\tau}(\beta), \tau=1 \ldots . N, N=$ $n T$ be a vector of simulated time series obtained from the model, where $\beta$ is the $5 \times 1$ vector of free parameters. Define $H_{x}(T)$ to be a $p \times 1$ vector of statistics of $x_{t}$, computed using a sample of size $T$ which includes unconditional moments of the cross sectional average monthly nominal profits on the dollar for each of the two maturities. Define $H_{y}(N, \beta)$ to be 
the corresponding $p \times 1$ vector of statistics for $y_{\tau}(\beta)$ computed using a sample of size N. A simulated estimator $\hat{\beta}(T, N)$ is obtained by minimizing:

$$
Q(\beta)=\left(H_{x}(T)-H_{y}(N, \beta)\right)^{\prime} W(T, N)\left(H_{x}(T)-H_{y}(N, \beta)\right)
$$

for a given random weighting matrix $W(T, N)$ with $\operatorname{rank}\{W(T, N)\} \geq \operatorname{dim}(\beta)$. The matrix $W(T, N)$ defines the metric for the problem and is assumed to converge almost surely to a nonstochastic matrix $W(0)$. Following Lee and Ingram, an optimal choice for $W(0)$ is given by:

$$
\begin{gathered}
W(0)=\left(\left(1+n^{-1}\right) S\right)^{-1} \\
S=\operatorname{diag}\left(\sum_{j} R_{x_{i}}(j)\right)=\operatorname{diag}\left(\sum_{k} R_{y_{i}}(j)\right)
\end{gathered}
$$

where the last equality holds under the null hypothesis that the $\beta$ are chosen correctly and where $R_{x_{i}}(j)$ and $R_{y_{i}}(j)$ are the autocovariance functions of the statistics of the actual and of the simulated data, $i=1, \ldots, 6$. Duffie and Singleton (1990) show that under fairly general mixing conditions $\hat{\beta}(T, N)$ is consistent and asymptotically normal ${ }^{3}$. Also, when the dimension of $\beta$ is smaller than the dimension of $H$, a goodness of fit test for the model is $T\{Q[\hat{\beta}(T, N)]\} \sim \chi^{2}(p-5)$. In our case an estimate for $S$ is computed by smoothing 12 sample autocovariances with a set of Parzen weights. Following Newey and West (1987) it is immediate to show that $\hat{S}_{T}$ is a consistent estimator of $S$.

Minimization of (11) is undertaken numerically ${ }^{4}$. We estimate the free parameters of the model in two ways. First, we match the actual time series for $k=1$ and $k=3$ separately using 6 statistics (unconditional mean, unconditional variance and the first four unconditional autocorrelations). In this case there is one overidentifying restriction for each maturity. Second, we estimated free parameters by jointly matching the properties of the unconditional mean, the unconditional variance and the first four unconditional autocorrelations of profits

\footnotetext{
${ }^{3}$ Since in our model $E P_{t, k}$ is a GARCH process, there is no insurance that the mixing conditions of Duffie and Singleton necessary to prove asymptotic normality hold in our case. However, given the results of Hansen (1991), we expect GARCH processes to satisfy some type of mixing conditions.

${ }^{4}$ Since the function $Q$ is not well behaved, a hill climbing routine produces values for the gradient which are too small to move away from initial estimates. The procedure we employ evaluates $Q$ at five successive grids. Each grid requires $5^{5}=3125$ evaluations of $\mathrm{Q}$ and is constructed around the minimum of the previous grid. On an 25-mhz 486 machine using the RATS random number generator and the seed command set equal to 2 , the total computation time for the grid search was about 50 minutes. Given simulation results contained in Gourieroux and Monfort (1991), we set $n=10$ in estimating the free parameters.
} 
for $k=1$ and $k=3$. In this second case there are 7 overidentifying restrictions. The estimated values for $\beta$ and the minimized value of $Q$ for the two different specifications are as follows (asymptotic standard errors are in parenthesis):

\begin{tabular}{ccccccc}
\hline \hline Maturity & $\gamma$ & $a_{15}$ & $a_{25}$ & $a_{16}$ & $a_{26}$ & $\mathrm{Q}(\hat{\beta})$ \\
\hline \hline$k=3$ & 0.3971 & 0.2105 & 0.2150 & 0.1508 & 0.2012 & 5.01 \\
& $(.2108)$ & $(.0956)$ & $(.0713)$ & $(.1248)$ & $(.1003)$ & \\
& & & & & & \\
$k=1$ & 0.0001 & 0.1206 & 0.1150 & 0.0972 & 0.0821 & 2.72 \\
& $(.1661)$ & $(.1562)$ & $(.1913)$ & $(.1223)$ & $(.1881)$ & \\
$k=1$ and $k=3$ & 0.9931 & 0.2385 & 0.1248 & 0.0145 & 0.0579 & 272.31 \\
& $(.1901)$ & $(.1133)$ & $(.1404)$ & $(.1372)$ & $(.2153)$ &
\end{tabular}

We simulate a time series for $E P_{t, k}$ of the same length as the actual data using the estimated $\hat{\beta}$ vectors and the unconditional variances of the exogenous processes as initial conditions. Figures 1 and 2, panel B plot the realizations for $k=3$ and $k=1$ respectively and their estimated MA representation when the parameters of the two specifications are fitted separately. Tables 1 and 2 , column 7 present the statistics of these simulated series and diagnostic tests for nonlinearities in their conditional moments, while column 8 presents statistics for the simulated series when $\beta$ is estimated jointly matching statistics for both $k=1$ and $k=3$.

A few features of the results deserve comment. First, when the free parameters are jointly fit to both maturities, the minimized value of the function is very large and the overidentifying restrictions strongly rejected. The model is much better when the parameters are fit to each holding maturity separately, suggesting that the properties of realized profits are not very alike across maturities. However, because of the large standard errors, the estimated parameters for the conditional variance of government expenditure shares in the two cases are not significantly different. Despite this feature, the volatility and serial correlation properties of simulated profits in the two cases do differ significantly. Second, the estimated values for the risk aversion parameter are small. In fact, when parameters are fit separately to each maturity we find that for $k=1$, the utility function is linear in aggregate consumption.

Third, when the parameters are fit separately to each maturity, the model does fairly well 
in matching the second order properties of the two actual series. For simulated 1 month profits the unconditional volatility is about two thirds of what we see in the actual data but for three month profits it is of the same order of magnitude as the data. On the other hand, the autocorrelation function of simulated 1 month profits matches well and for simulated three month profits the first order serial correlation coefficient is about two thirds of what we see in the data. The presence of this error for $k=3$ is also detectable in the plot of the MA representation which decays too fast when compared with the estimated MA of the cross sectional average nominal profits on the dollar. For the five currencies we use in table 2, Backus, Gregory and Telmer (1990) report experiments where with moderate risk aversion and time additive preferences the simulated variability of expected profits is less than five percent of the variability of actual profits. With heteroschedastic driving forces we managed to push up the variability of simulated profits in the range of the variability of actual profits for both maturities, while keeping time additive preferences and very low risk aversion.

Finally, the simulated data display no nonlinearities and the first two conditional moments of the simulated expected profits and of the actual cross sectional profits have largely similar properties for both maturities.

\section{Some Explanations and Sensitivity Analysis}

The above simulations indicate that the model replicates several time-series properties of the cross sectional average nominal profits on the dollar reasonably well. Since previous attempts to account for these properties using artificial economies have failed, some explanations are in order.

In a standard consumption based asset pricing model equilibrium expected profits of a risky asset typically depend on the conditional covariance between the marginal utility of consumption and the real payoff of the risky asset. Any asset that tends to pay a low real return in states where agents are poor (marginal utility is high) will require a positive premium to induce agents to hold it. The real payoff of the risky asset in turns depends on the distributional properties of the underlying exogenous forces of the economy. In general, the conditional variability of the exogenous processes affects both the expected payoff of the risky 
asset and the expected marginal utility of consumption and therefore matters for the level of profits. However, since the conditional variability is generally assumed to be constant, it plays no role in explaining the volatility and serial correlation properties of realized nominal profits.

For the case of exchange rate markets, the excess profits required for taking a risky position in one currency is linked to the covariation of the marginal utility of consumption with the purchasing power of the currency (see e.g. Hodrick and Srivastava (1984), Sibert (1989)). Attempts by Hansen and Hodrick (1980), Hodrick and Srivastava (1984), Mark (1985) and others to fit the model to exchange rate data using the Euler equations of the model and a Generalized Method of Moments (GMM) procedure were generally unsuccessful. Their failures stem from being unable to reconcile the small variability in aggregate consumption data with the volatile and serially correlated nature of realized profits from forward speculation. In their models the time series properties of expected profits are determined entirely by time variation in the conditional covariances. The conditional second moments of the exogenous processes are assumed to be constant.

This paper follows Hodrick (1989) and isolates the influence of the conditional second moments of the exogenous processes on the time series properties of expected profits. This is accomplished in two ways. First, since evidence presented in Hansen and Hodrick (1983), Engel (1990), Hakkio and Sibert (1990) indicates that conditional covariances can not account for the behavior of excess profits, we abstract from them entirely by assuming that the exogenous processes are conditionally independent. Second, we allow the conditional second moments of money supplies and government expenditures to be time varying. Thus, if there is enough volatility and serial correlation in these conditional moments, expected profits will also be volatile and serially correlated.

Next, we proceed to identify what specific features of the model are responsible for the results. In particular, we are interested in assessing the relative contribution of the conditional variance of the money supplies and of government consumption shares in fitting the second order properties of nominal profits and whether the time series properties of expected profits arise from risk adverse behavior. This is done by conducting two experiments. First, we restrict the share of government purchases to have constant conditional variances and examine 
the properties of the resulting expected profits series leaving all other parameters at their optimal values.

Because of the poor fit of the model when $\beta$ is jointly estimated for $k=1$ and $k=3$, we report results for the first specification only. From Tables 1 and 2, column 9 it is evident that setting $\operatorname{var}_{t}\left(\Phi_{i t}\right)=\operatorname{var}\left(\Phi_{i t}\right) \forall t$ significantly affects the entire moment structure of the simulated expected profits. Since variations over time in the conditional variances of the two money supply processes are the only sources of variability and serial correlation in $E P_{t, k}$, one can see that very little of the second order properties of the original $E P_{t, k}$ come from these series.

To see intuitively why fluctuations in the conditional variability of government expenditure shares affect expected profits, note that, under the assumptions made, an expected increase in the conditional variance of the domestic government expenditure share decreases the expected price of domestic currency relative to the foreign currency. Therefore, traders require higher nominal expected profits to engage in speculative transactions in a currency that is expected to depreciate in the future ( see also Black (1990)).

Second, we consider the question of whether fluctuations in the simulated expected profits arise from risk averse behavior of agents. By now it is widely recognized that even when agents are risk neutral, efficiency in the foreign exchange market does not dictate that expected nominal profits are zero. Expected profits can be measured in terms of either currency. When the purchasing powers of the currencies are uncertain, Jensen's inequality implies that expected profits must exist, at least in terms of one of the two currencies.

We can decompose the simulated expected nominal profits into a component arising entirely from risk averse behavior and another due to Jensen's inequality (a "convexity" term). The convexity term is computed by simulating the model under the assumption that agents are risk neutral, i.e. by setting $\gamma=0$. The risk premium is then obtained by subtracting the resulting series from $E P_{t, k}$. Unlike $E P_{t, k}$, the risk premium series has the property that it will identically equal zero when agents are risk neutral.

Table 1, column 11 report statistics for the nominal risk premium for $k=3$. For $k=1$ the risk premium is zero everywhere because the estimated value of $\gamma$ is for all purposes 0 , so that the properties of the simulated profit series are entirely due to the convexity term. 
The risk premium is on average significantly positive (i.e. the basket of foreign currencies is on average more risky than the dollar) while simulated nominal expected profits were, on average, significantly negative, suggesting that, at some point in time, the two series may have opposite signs (see also Hakkio and Sibert (1990)). In addition, we find that the risk premium has a large variance and a moderate degree of persistence. Therefore, contrary to the case of $k=1$, the variability and autocorrelation properties of expected profits are much more closely related to those of the risk premium than the convexity term.

Although the independence assumptions may have resulted in an underestimation of some time series properties of the risk premium (especially for $k=1$ ), the results obtained make it clear that the error in identifying the risk premium with expected nominal profits may be larger than was previously recognized. Engel (1990) proposes a method for constructing a measure of the risk premium that is related to expected real profits and likely to be more relevant in capturing the response of agents to risk. Hakkio and Sibert (1990) examine the properties of four different measures of expected profits (two real and two nominal) with data simulated from an OG model. Since little empirical work has been done to characterize the behavior of appropriately measured real risk premia in the actual world, further studies are necessary to determine the importance of risk considerations for the dynamics of foreign exchange markets.

Finally, since the SMM estimate of the parameters differ across the two holding periods, we would like to know whether the properties of the time series generated with the alternative specification significantly differ from the other. Column 10 of table 1 reports the results of inputting in the model for $k=3$ the parameters estimated with $k=1$ while column 10 of table 2 reports the results of simulating an expected profits series for $k=1$ using the parameters estimated with $k=3$. The results indicate that for both holding periods expected profits series are substantially different from the specifications presented in column 7 of both tables, supporting recent speculations of Lewis (1991) that the properties of ICCAP model may depend on the holding period used to calculate expected profits. In particular, we find that all the second moment properties of simulated expected profits for $k=3$ are altered and for $k=1$ simulated profits are conditionally heteroschedastic ${ }^{5}$.

\footnotetext{
${ }^{5}$ We also conducted experiments changing some of the assumptions of the model. For example, we allowed
} 


\section{Properties of consumption, spot and forward rates}

The relevance of our findings depends on whether the theoretical implications for other variables are also born out by the data. In particular, since previous failures of the standard asset pricing paradigm stemmed largely from the low variability in aggregate consumption data, we would like to be certain that the simulations do not induce excess variability in the generated consumption series. It is easy to show that this is not the case since we imposed the consistency condition on the quarterly unconditional moments of government expenditure shares.

The variability of equilibrium consumption growth relative to the variability of output growth $W=\frac{\operatorname{var}\left(\Delta \log C_{t}\right)}{\operatorname{var}\left(\Delta \log Y_{1 t}\right)}$ is given by:

$$
W=\frac{\operatorname{var}\left[\delta\left[\Delta \log \left(1-z_{5 t+1}\right)\right]+(1-\delta)\left[\Delta \log \left(1-z_{6 t+1}\right)\right]+\delta z_{1 t+1}+(1-\delta) z_{2 t+1}\right]}{\operatorname{var}\left[z_{1 t+1}\right]}
$$

For the simulated monthly realization reported in figure 1, taking the actual values for the growth rate of industrial production in the US and in OECD countries as measures of output growth, $\mathrm{W}$ is 0.1898 . Using monthly data for the $1975-90$ period for real U.S. consumption and industrial production this ratio is estimated to be $0.2156{ }^{6}$. Therefore, the simulations do not induce excess volatility in consumption.

To further examine the implications of the model we check the properties of simulated spot and forward rates. One way of summarizing the information contained in the simulations is to examine whether the forward rate is an unbiased predictor of future spot rates. This property is typically tested by running one of the following two complementary regressions:

$$
\begin{aligned}
f_{t, k}-s_{t+k} & =a_{1}+b_{1}\left(f_{t, k}-s_{t}\right)+u_{t+k} \\
s_{t+k}-s_{t} & =a_{2}+b_{2}\left(f_{t, k}-s_{t}\right)+e_{t+k}
\end{aligned}
$$

for a structural break in the US money supply process in 1979, 1982 and 1985 and we allowed innovations in government expenditure to be correlated with output innovations. None of these modifications appear to be useful in improving the fit of the model.

${ }^{6}$ Backus and Kehoe (1987), using different quarterly data detrended with the Hodrick and Prescott filter over the entire post WWII period set this ratio at a higher .65 . One reason for this difference is that, over the entire post WWII period, the volatility of the share of US government expenditure is much larger than over the 75-90 period. Another explanation is that detrending the data using the Hodrick and Prescott filter induces different time series properties than a log difference filter (see Canova (1991)). Finally, it should be mentioned that any estimate for monthly consumption should be taken with a grain of salt because of the dubious statistical properties of available monthly consumption series (see e.g. Wilcox (1988)). 
where $f_{t, k}$ and $s_{t}$ are the logs of the forward and spot rates. The unbiasedness hypothesis implies that $a_{1}=b_{1}=0.0$ or alternatively $a_{2}=-a_{1}$ and $b_{2}=1-b_{1}$. The essence of the test is that when the forward rate exceeds the spot rate, we expect the future spot rate to rise by the same amount. It is well known that the null hypothesis is strongly rejected in the actual data for various currencies, samples and frequencies (see e.g. Frankel and Meese (1987) or Hodrick (1987)). In many cases $b_{2}$ turns out to be significantly negative suggesting a failure of the simple expectational theory in both level and sign.

Table 5 reports the regression results for our two available data sets. The general pattern of results is consistent with previous evidence. For three month profits and except for the French Franc/\$ rate all the $b_{2}$ coefficients are significantly negative. For 1 month profits they are all negative but insignificantly different from zero.

To determine whether our model can reproduce this biasedness, we generate artificial data for spot and forward rates using the closed form expressions for (3) and (5) when the $\beta$ vector is fitted separately for $k=1$ and $k=3$, and then run a regression like (15) on the simulated data to estimate $a_{2}$ and $b_{2}{ }^{7}$. We report two sets of results. One obtained using the simulated method of moment (SMM) estimates of the free parameters for each of the two maturities. Another obtained by randomizing over the free parameters using their asymptotic distribution. That is, for each draw $q$ and each maturity $k$ we simulate $\left\{s_{t}\left(\beta_{q}\right)\right\}_{t=1}^{T},\left\{f_{t, k}\left(\beta_{q}\right)\right\}_{t=1}^{T}$ where $\beta_{q} \sim N\left(\beta_{S M M}, \operatorname{var}\left(\beta_{S M M}\right)\right)$ and where $\operatorname{var}\left(\beta_{S M M}\right)$ is the asymptotic covariance matrix of $\beta_{S M M}$, the SMM estimator of $\beta$. In this case we report the $90 \%$ range of the simulated distribution for $a_{2}$ and $b_{2}$ and the median value of the distribution when $q=10000$.

The results indicate that the biasedness observed in the actual data also emerges in our simulated data. For the three month realized profits, the $b_{2}$ coefficient is negative in $61 \%$ of the simulations and the largest obtained value is 0.77 (the unbiasedness hypothesis would suggest a value of 1 ). For 1 month profits the $90 \%$ range for both regression parameters include the values obtained in the actual data for the average cross sectional series.

One way to understand these results is to look at equations (3) and (5). While changes in

\footnotetext{
${ }^{7}$ To simulate a time series for the forward rate we need to select four extra parameters regulating the conditional means of the two money supply processes, which are reported table 4.
} 
the conditional variance of the exogenous processes affect the forward rate and the expected spot rate, they do not appear in the formula for realized spot rate. Therefore fluctuations over time in the conditional second moments affect the forward premia and the realized change in the spot rate differently, leading to a forecast error in predicting changes in the spot rate which are not serially uncorrelated, homoschedastic and exogenous. Running a regression like (15) therefore misses the underlying dynamics of the data. Contrary to the arguments in Domowitz and Hakkio (1985), the presence of heteroschedasticity in the processes generating expected profits does not only affect the estimate of the intercept in the regression. The entire regression line is shifted from what would be expected under the simple expectational hypothesis.

\section{Conclusions}

This paper attempts to replicate the statistical properties of realized nominal profits from forward speculation on the dollar using a general equilibrium monetary model where agents are rational and fundamentals drive exchange rate behavior. It explores the influence of time variation in the conditional variability of the exogenous processes on the time series properties of nominal expected profits. We find that the presence of conditional heteroschedasticity is important in generating time series which are volatile and exhibit autocorrelation properties which are similar to those of the cross sectional realized average nominal profits on the dollar. We also find that the risk component of expected profits does not necessarily account for many interesting properties of the data and that simulated forward rates are biased predictors of simulated future spot rates.

Three important conclusions emerge from our study. First, an ICCAP model appropriately formulated may help account for some of the puzzling time series features of nominal profits on the dollar. This class of models therefore has the potential to explain other anomalies (the equity premium, the holding and forward premium in the term structure of interest rates) recently discovered in financial markets. Second, forecast errors may not be so crucial in explaining the surge in volatility experienced in foreign exchange markets during the 80 's. Third, the identification of the expected component of profits with a risk premium may lead to fallacious conclusions about the nature and sources of risk in foreign exchange markets. 


\section{Appendix}

The expressions for $\mathcal{G}_{5 t}$ and $\mathcal{G}_{6 t}$ used in section 3 are given by

$$
\begin{aligned}
\mathcal{G}_{5 t} & =-\frac{\left(1-h_{5 t, k}\right)}{h_{5 t, k}} \log \left(1-h_{5 t, k}\right)-\log \left[1-\left(1-h_{5 t, k}\right)^{(1+\delta)(1-\gamma)}\right] \\
& +\log \left[1-\left(1-h_{5 t, k}\right)^{\delta(1-\gamma)}\right] \\
\mathcal{G}_{6 t} & =-\frac{\left(1-h_{6 t, k}\right)}{h_{6 t, k}} \log \left(1-h_{6 t, k}\right)-\log \left[1-\left(1-h_{6 t, k}\right)^{(1-\delta)(1-\gamma)}\right] \\
& +\log \left[1-\left(1-h_{6 t, k}\right)^{(1+(1-\delta)(1-\gamma))}\right]
\end{aligned}
$$

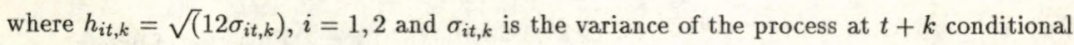
on information available at time $t$. 


\section{References}

[1] Baillie, R. and Bollerslev, T., 1990, "A Multivariate Generalized ARCH Approach to Modelling Risk Premia in Forward Foreign Exchange Markets", Journal of International Money and Finance 9, 309-324.

[2] Backus, D. and Gregory, W., 1989, "Risk Premiums in Asset Prices and Returns," Comment to R.T. Baillie, "Econometric Tests of Rationality and Market Efficiency," Econometric Reviews 8, 187-196.

[3] Backus, D., Gregory, W. and Telmer, C., 1989, "Accounting for Forward Rates in Markets for Foreign Currencies", Federal Reserve Bank of Minneapolis, working paper 439, forthcoming, Journal of Finance.

[4] Backus, D., Gregory, W. and Zin, S., 1989, "Risk Premium in the Term Structure: Evidence from Artificial Economies," Journal of Monetary Economics 24, 371-400.

[5] Backus, D. and Kehoe, P., 1987, "International Evidence on the Historical Properties of Business Cycles", Federal Reserve Bank of Minneapolis, working paper 402R.

[6] Bekaert, G., 1991, "Exchange Rate Volatility and Deviations from Unbiasedness in Cash-inAdvance Models ", Northwestern University, manuscript.

[7] Black, F., 1990, "Exchange Rate Hedging", Journal of Finance, XLV, 899-907.

[8] Breeden, D., 1986, "Consumption, Production, Inflation and Interest Rates: A Synthesis ", Journal of Financial Economics, 16, 3-39.

[9] Breush, T. and Pagan, A., 1979, "A Simple Test for Heteroschedasticity and Random Coefficient Variation," Econometrica 47, 1284-1294.

[10] Brock, W. and Dechert, W., 1988, "A General Class of Specification Tests: The Scalar Case," University of Wisconsin, manuscript.

[11] Canova, F., 1991, "Detrending and Business Cycle Facts", Brown University, manuscript.

[12] Cumby, R., 1988, "Is it Risk? Explaining Deviations from Uncovered Interest Parity," Journal of Monetary Economics 22, 279-300.

[13] Cumby, R. and Huizinga, J., 1990, "Testing the Autocorrelation Structure of Disturbances in Ordinary Least Squares and Instrumental Variable Regressions", NBER technical working paper, 92.

[14] Diebold, F., 1988, Empirical Modelling of Exchange Rate Dynamics, (Springer Verlag, New York, N.Y.).

[15] Domowitz, I. and Hakkio, C, 1985, "Conditional Variance and the Risk Premium in the Foreign Exchange Markets", Journal of International Economics, 19, 47-66.

[16] Duffie, D. and Singleton, K., 1990, "Simulated Moments Estimation of Markov Models af Asset Prices”, NBER, technical working paper 87 .

[17] Engel, C., 1990, "On the Foreign Exchange Risk Premium in a General Equilibrium Model", University of Virginia, manuscript.

[18] Fama, E., 1984, "Forward and Spot Future Rates", Journal of Monetary Economics 14, 319-328.

[19] Flood, R., 1988, "Asset Prices and Time Varying Risk" International Monetary Fund, Working Paper 88-42. 
[20] Frankel, J., 1986, "The Implication of Mean-Variance Optimization for Four Questions in International Macroeconomics," Journal of International Money and Finance 5 (supplement), s53-s75.

[21] Frankel, J. and Froot, K., 1987, "Using Survey Data to Test Standard Propositions Regarding Exchange Rate Expectations," American Economic Review 77, 133-53

[22] Frankel, J. and Meese, E., 1987, “Are Exchange Rates Excessively Variable?," NBER Macroeconomics Annual, 118-153.

[23] Frenkel, J. and Razin A., 1980, "Stochastic Prices and Tests of Efficiency of Foreign Exchange Markets", Economic Letters 6, 165- 170.

[24] Froot, K. and Frankel, J., 1989, "Forward Exchange Rate Bias: Is it an Exchange Risk Premium?," Quarterly Journal of Economics, 103, 139-161.

[25] Giovannini, A. and Jorion, P., 1987, "Interest Rates and Risk Premia in the Stock Market and in the Foreign Exchange Market," Journal of International Money and Finance 6, 107-124.

[26] Giovannini, A. and Jorion, P., 1988, "Foreign Exchange Risk Premia Volatility Once Again" Journal of International Money and Finance 7, 111-113.

[27] Giovannini, A. and Labadie, P., 1989, " Asset Prices and Interest Rates in Cash in Advance Models", National Bureau of Economic Research, working paper 3109.

[28] Gourieroux, C. and Monfort, A., 1991, "Simulation Based Econometrics in Models with Heterogeneity", Annales d'Economie et de Statistique, 20-21.

[29] Hakkio, C. and Sibert, A., 1990, "An Equilibrium Model of Spot and Forward Exchange Rates", Federal Reserve Bank of Kansas City, manuscript.

[30] Hansen, B., 1991, “GARCH(1,1) Are Near Epoch Dependent”, Economic Letters, 36, 181-186.

[31] Hansen, L.P. and Hodrick, A., 1980, "Forward Exchange Rates as Optimal Predictors of Future Spot Rates: An Econometric Analysis," Journal of Political Economy 88, 829-853.

[32] Hansen, L.P. and Hodrick, A., 1983, "Risk Averse Speculation in Forward Foreign Exchange Market: An Econometric Analysis of Linear Models" in : J.A. Frenkel, ed., Exchange Rates and International Economics, (University of Chicago Press for the National Bureau of Economic Research, Chicago, IL.).

[33] Hodrick, R., 1987, The Empirical Evidence on the Efficiency of Forward and Future Foreign Exchange Markets, (Harwood Academic Press, Chur, Switzerland).

[34] Hodrick, R., 1989, "Risk, Uncertainty and Exchange Rates," Journal of Monetary Economics, $23,433-460$.

[35] Hodrick, R., Kocherlakota, N. and Lucas, D., 1991, "The Variability of Velocity in Cash-inAdvance Models," Journal of Political Economy, 99, 358-384.

[36] Hodrick, R. and Srivastava, S., 1984, "An Investigation of Risk and Return in Forward Foreign Exchange," Journal of International Money and Finance, 2, 5-29.

[37] Kaminsky, G., 1989, "The Peso Problem and the Behavior of the Exchange Rate: The Dollar/Pound Exchange Rate 1976-1987," UCSD Working Paper 89-5.

[38] Ingram, B. and Lee, B.S., 1991, "Estimation by Simulation," Journal of Econometrics 47, 197-207.

[39] Lewis, K., 1989, "Changing Beliefs about Fundamentals and Systematic Rational Forecast Errors: With Evidence from Foreign Exchange Markets," American Economic Review 79, 621-636. 
[40] Lewis, K., 1991, "Should the Holding Period Matter for the Intertemporal Consumption Based CAPM ?," NBER working paper 3583 .

[41] Lucas, R., 1982, "Interest Rates and Currency Prices in a Two Country World," Journal of Monetary Economics 16, 335-360.

[42] McCulloch.H., 1975, "Operational Aspects of Siegel Paradox", Quarterly Journal of Economics $89,170-172$.

[43] Macklem, T., 1991, "Forward Exchange Rates in Artificial Economies", Journal of International Money and Finance, 10, 365-391.

[44] Mark, N., 1985, "On the Time Varying Risk Premia in Foreign Exchange Markets: An Econometric Analysis," Journal of Monetary Economics 16, 3-18.

[45] Merha, R. and Prescott, E.C., 1985, "The Equity Premium: A Puzzle", Journal of Monetary Economics 15, 145-168.

[46] Newey, W. and West, K., 1987, "A Simple, Positive Semidefinite Heteroschedasticity and Autocorrelation Consistent Covariance Matrix," Econometrica 55, 703-708.

[47] Sibert, A., 1989, "The Risk Premium in Foreign Exchange Markets" Journal of Money, Credit and Banking 21, 49-65

[48] White, H., 1980, "A Heteroschedastic Consistent Covariance Matrix Estimator and Direct Tests for Heteroschedasticity," Econometrica 48, 817-838.

[49] Wilcox, J, 1988, "What Do We Know About Consumption", Board of Governors, Federal Reserve System, manuscript. 


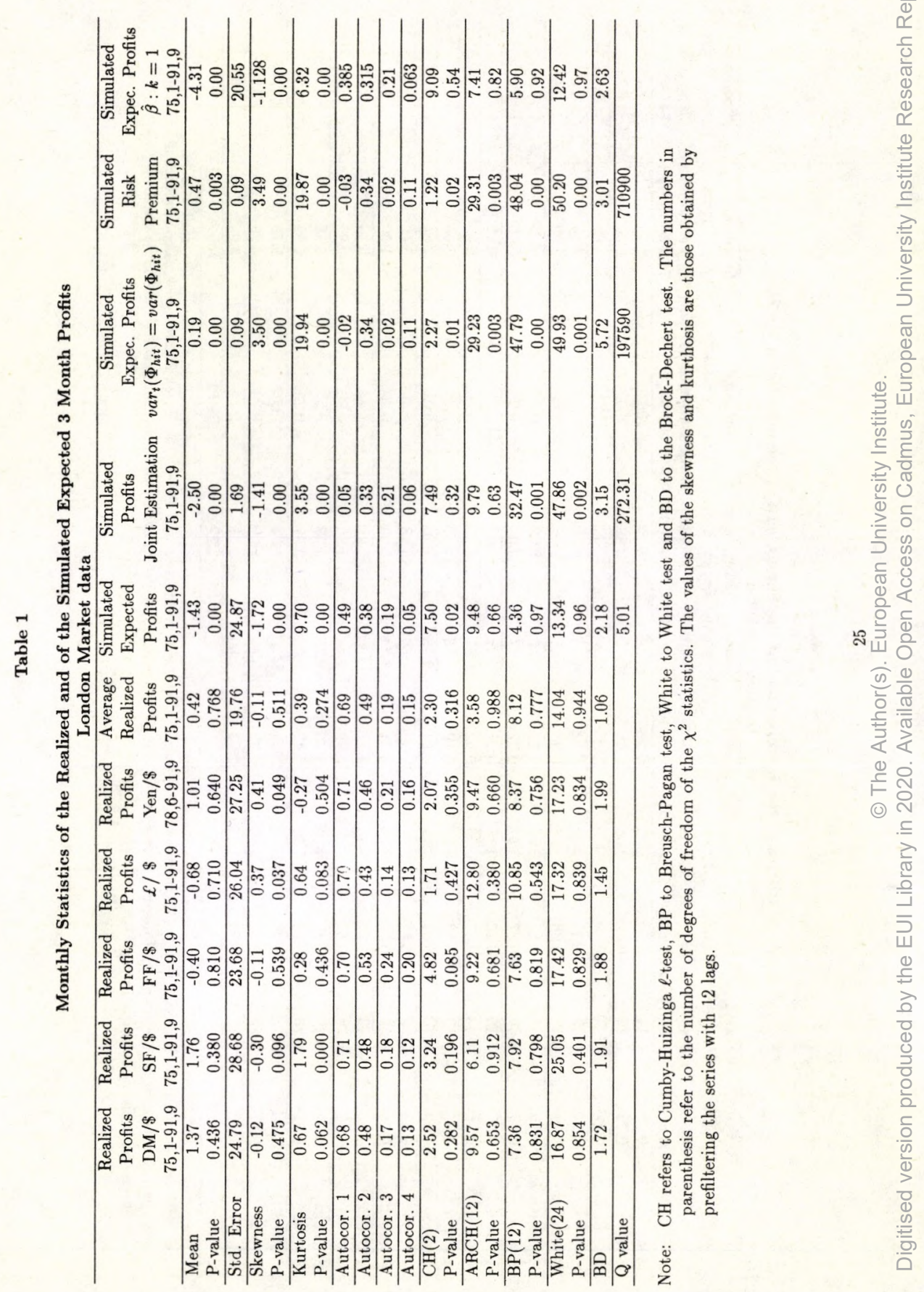




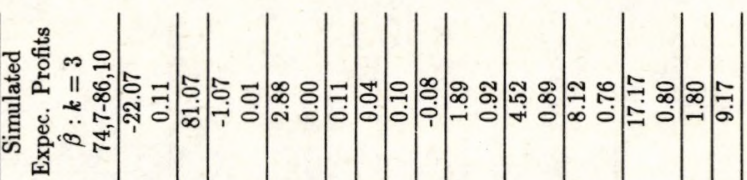

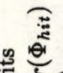

承

๘

चี

के

营

要

융 윰

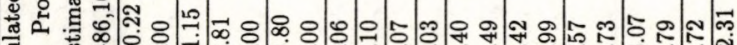

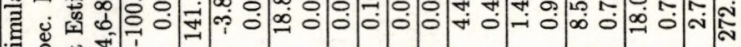

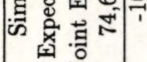

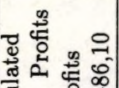

西

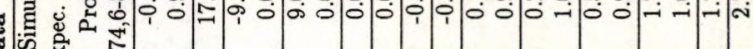
毒勋

N

ত

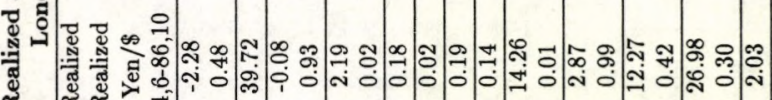

저

퓼

露

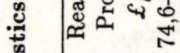

要

Ð

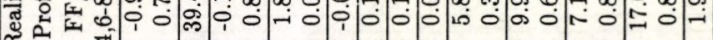

覀

용 $\infty$

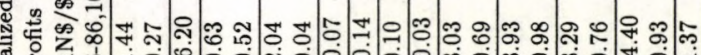
『ే $\approx 20$

ॠ

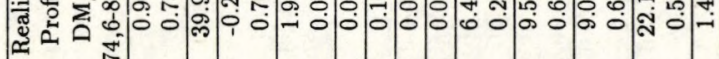

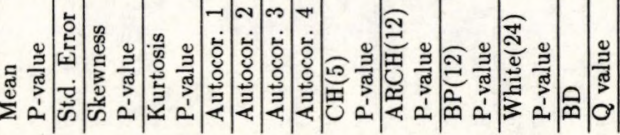

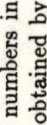
है

就

녕

혼

늘

둘 :

$\circ$ 원

कิ ฐ

ซี

苞密

进

요

营

牙尔

동

กั

논

究

월

คิ

क्षे

2.

造者

을

定造

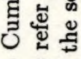

$+\frac{\infty}{8 .}$

造离焉

范范

ง

¿

() 
Table 3

Diagnostic Tests for Serial Correlation, Heterosckedasticity and Normality in the Exogenous Processes.

Sample 75,1-90,12. Significance Levels

\begin{tabular}{|c|c|c|c|c|c|}
\hline Series & $\mathrm{CH}(6)$ & ARCH(12) & $\mathrm{BP}(12)$ & $\mathrm{W}(24)$ & $\mathrm{BD}$ \\
\hline M1OECD & $\begin{array}{l}3.94 \\
(0.80)\end{array}$ & $\begin{array}{l}90.48 \\
(0.00)\end{array}$ & $\begin{array}{l}61.72 \\
(0.00)\end{array}$ & $\begin{array}{l}108.37 \\
(0.00)\end{array}$ & 2.12 \\
\hline M1 & $\begin{array}{l}2.00 \\
(0.91)\end{array}$ & $\begin{array}{l}26.62 \\
(0.008)\end{array}$ & $\begin{array}{l}6.71 \\
(0.87)\end{array}$ & $\begin{array}{l}31.17 \\
(0.14)\end{array}$ & 1.88 \\
\hline
\end{tabular}

Sample Cross Correlations of Univariate Residuals: M1-M1OECD Sample 75,1-90,12

\begin{tabular}{cccccc}
\hline \hline \multicolumn{3}{c}{ Residuals } & & \multicolumn{1}{c}{ Squared Residuals } \\
\hline-1 & 0 & 1 & -1 & 0 & 1 \\
-0.11 & 0.13 & 0.00 & 0.03 & -0.07 & 0.13
\end{tabular}

Notes: CH refers to Cumby-Huizinga $\ell$-test, BP refers to Breush-Pagan test, W to White test and BD to the Brock-Dechert test. For each series a log first order difference transformation is used and residuals are prewhiten using one lag. The number next to each test refers to the number of degrees of freedom of the test. In parenthesis in the first panel are the significance levels of the statistics.

Table 4

Estimated GARCH Specification for the Exogenous Processes Model: $\Delta \log y_{t}=A_{0}+A_{1} * \Delta \log y_{t-1}+\epsilon_{t}$ $h_{t}=a_{0}+a_{1} * h_{t-1}+a_{2} \epsilon_{t-1}^{2}$

\begin{tabular}{lllllll}
\multicolumn{8}{c}{$h_{t}=a_{0}+a_{1} * h_{t-1}+a_{2} \epsilon_{t-1}^{2}$} \\
\hline \hline Sample & Variable & $a_{0}$ & $a_{1}$ & $a_{2}$ & $A_{0}$ & $A_{1}$ \\
\hline \hline \multirow{2}{*}{$75-90$} & \multirow{4}{*}{ M1OECD } & 0.0005 & -0.0003 & 0.16 & 0.009 & -0.21 \\
& & $(6.41)$ & $(-0.003)$ & $(1.14)$ & $(3.77)$ & $(-1.70)$ \\
& \multirow{2}{*}{ M1 } & 0.00002 & 0.000004 & 0.37 & 0.004 & 0.25 \\
& & $(5.39)$ & $(0.003)$ & $(2.68)$ & $(5.24)$ & $(2.43)$
\end{tabular}

Note: In parenthesis are t-statistics . 
Table 5A

Regression Results: Sample 75,7-91,9

Model: $\Delta^{3} s_{t}=a_{2}+b_{2} F P_{t, 3}+u_{t}$

\begin{tabular}{llll}
\hline Country & $a_{2}$ & $b_{2}$ & $R^{2}$ \\
\hline \hline & & & \\
WG & $-5.98(-1.69)$ & $-1.23(-1.37)$ & 0.01 \\
SW & $-10.11(-2.79)$ & $-1.42(-2.17)$ & 0.02 \\
FR & $2.01(0.90)$ & $0.07(0.13)$ & 0.001 \\
CA & $1.86(2.44)$ & $-0.87(-2.43)$ & 0.03 \\
UK & $7.64(3.54)$ & $-2.15(-4.11)$ & 0.07 \\
JP & $-22.05(-5.43)$ & $-4.03(-4.84)$ & 0.19 \\
NT & $-6.06(-2.44)$ & $-2.05(-2.79)$ & 0.04 \\
AVERAGE & $-4.20(-2.50)$ & $-2.31(-3.29)$ & 0.06 \\
SIMULATION & $-0.02(-2.01)$ & $-0.04(-1.17)$ & 0.006 \\
& {$[-0.26,2.56]$} & {$[-1.87,0.32]$} & {$[0.001,0.12]$} \\
& 0.72 & -0.08 &
\end{tabular}

Table 5B

Regression Results: Sample 74,8-86,10

Model: $\Delta s_{t}=a_{2}+b_{2} F P_{t, 1}+u_{t}$

\begin{tabular}{llll}
\hline Country & $a_{2}$ & $b_{2}$ & $R^{2}$ \\
\hline \hline & & & \\
CA & $-0.002(-2.05)$ & $-0.24(-0.35)$ & 0.008 \\
FR & $-0.002(-0.87)$ & $-0.49(-0.81)$ & 0.003 \\
WG & $0.003(0.70)$ & $-0.21(-0.16)$ & 0.0001 \\
JP & $0.009(3.30)$ & $-1.57(-2.16)$ & 0.02 \\
UK & $-0.003(-0.97)$ & $-0.42(-0.38)$ & 0.001 \\
AVERAGE & $0.0002(0.14)$ & $-1.04(-1.24)$ & 0.008 \\
SIMULATION & $0.026(2.33)$ & $0.21(3.47)$ & 0.099 \\
& {$[-0.01,0.05]$} & {$[-1.24,0.35]$} & {$[0.001,0.131]$} \\
& 0.002 & -0.12 &
\end{tabular}

Notes: In parethesis t-statistics. The first row of SIMULATION reports the regression results obtained when the data is generated with the optimal values of the parameters. The second row reports the $90 \%$ range of the simulated distribution for the regression coefficients obtained by drawing 10000 values for the parameters from their asymptotic distribution. The third row reports the median value of the simulated distribution for regression coefficients. 

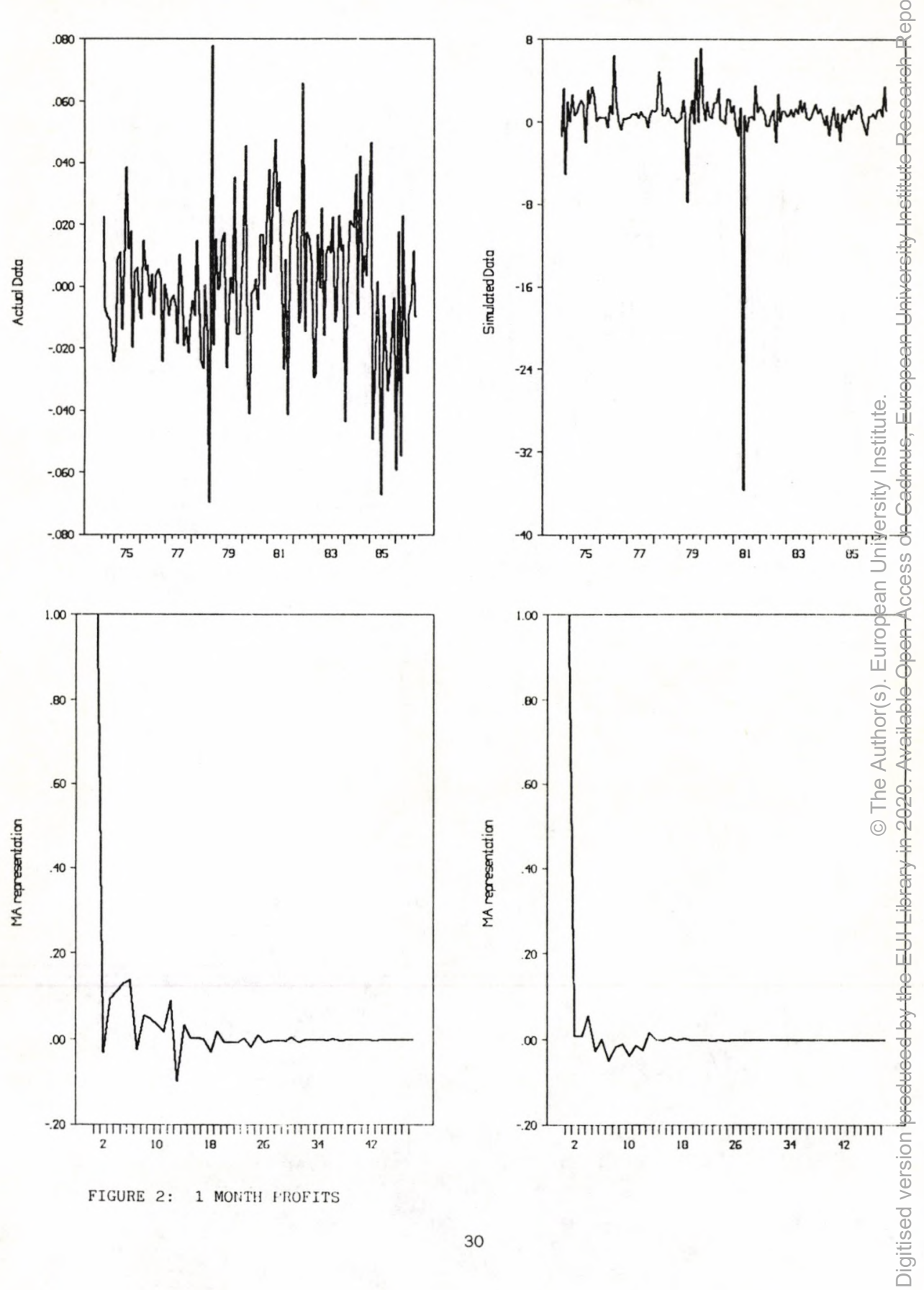


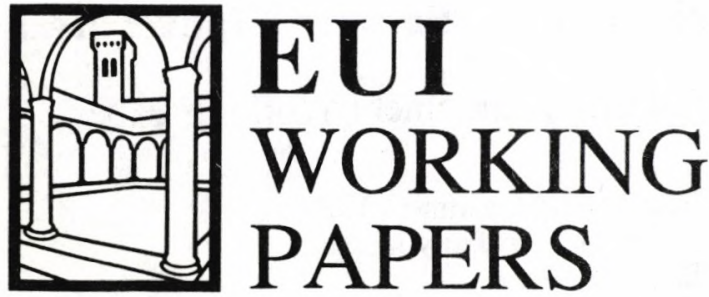

EUI Working Papers are published and distributed by the European University Institute, Florence

Copies can be obtained free of charge - depending on the availability of stocks - from:

The Publications Officer

European University Institute

Badia Fiesolana

I-50016 San Domenico di Fiesole (FI)

Italy

Please use order form overleaf 


\section{圆 \\ Publications of the European University Institute \\ Economics Department Working Paper Series}

To

Economics Department WP

European University Institute

Badia Fiesolana

I-50016 San Domenico di Fiesole (FI)

Italy

From Name

Address

(Please print)

ב Please enter/confirm my name on EUI Economics Dept. Mailing List

$\square$ Please send me a complete list of EUI Working Papers

$\square$ Please send me a complete list of EUI book publications

$\square$ Please send me the EUI brochure Academic Year 1992/93

Please send me the following EUI ECO Working Paper(s):

No, Author

Title:

No, Author

Title:

No, Author

Title:

No, Author

Title:

Date

Signature 


\section{Working Papers of the Department of Economics Published since 1990}

ECO No. 90/1

Tamer BASAR and Mark SALMON

Credibility and the Value of Information

Transmission in a Model of Monetary

Policy and Inflation

ECO No. $90 / 2$

Horst UNGERER

The EMS - The First Ten Years

Policies - Developments - Evolution

ECO No. 90/3

Peter J. HAMMOND

Interpersonal Comparisons of Utility:

Why and how they are and should be made

ECO No. 90/4

Peter J. HAMMOND

A Revelation Principle for (Boundedly)

Bayesian Rationalizable Strategies

ECO No. $90 / 5$

Peter J. HAMMOND

Independence of Irrelevant Interpersonal Comparisons

ECO No. 90/6

Hal R. VARIAN

A Solution to the Problem of

Externalities and Public Goods when

Agents are Well-Informed

ECO No. 90/7

Hal R. VARIAN

Sequential Provision of Public Goods

ECO No. 90/8

T. BRIANZA, L. PHLIPS and J.F.

RICHARD

Futures Markets, Speculation and

Monopoly Pricing

ECO No. 90/9

Anthony B. ATKINSON/ John

MICKLEWRIGHT

Unemployment Compensation and

Labour Market Transition: A Critical

Review

ECO No. 90/10

Peter J. HAMMOND

The Role of Information in Economics
ECO No. 90/11

Nicos M. CHRISTODOULAKIS

Debt Dynamics in a Small Open

Economy

ECO No. 90/12

Stephen C. SMITH

On the Economic Rationale for

Codetermination Law

ECO No. 90/13

Elettra AGLIARDI

Learning by Doing and Market Structures

ECO No. 90/14

Peter J. HAMMOND

Intertemporal Objectives

ECO No. 90/15

Andrew EVANS/Stephen MARTIN

Socially Acceptable Distortion of

Competition: EC Policy on State Aid

ECO No. 90/16

Stephen MARTIN

Fringe Size and Cartel Stability

ECO No. 90/17

John MICKLEWRIGHT

Why Do Less Than a Quarter of the

Unemployed in Britain Receive

Unemployment Insurance?

ECO No. 90/18

Mrudula A. PATEL

Optimal Life Cycle Saving With

Borrowing Constraints:

A Graphical Solution

ECO No. 90/19

Peter J. HAMMOND

Money Metric Measures of Individual and Social Welfare Allowing for

Environmental Externalities

ECO No. 90/20

Louis PHLIPS/

Ronald M. HARSTAD

Oligopolistic Manipulation of Spot

Markets and the Timing of Futures

Market Speculation 
ECO No. 90/21

Christian DUSTMANN

Earnings Adjustment of Temporary

Migrants

ECO No. 90/22

John MICKLEWRIGHT

The Reform of Unemployment

Compensation:

Choices for East and West

ECO No. 90/23

Joerg MAYER

U. S. Dollar and Deutschmark as

Reserve Assets

ECO No. 90/24

Sheila MARNIE

Labour Market Reform in the USSR:

Fact or Fiction?

ECO No. 90/25

Peter JENSEN/

Niels WESTERGÅRD-NIELSEN

Temporary Layoffs and the Duration of

Unemployment: An Empirical Analysis

ECO No. 90/26

Stephan L. KALB

Market-Led Approaches to European

Monetary Union in the Light of a Legal

Restrictions Theory of Money

ECO No. 90/27

Robert J. WALDMANN

Implausible Results or Implausible Data?

Anomalies in the Construction of Value

Added Data and Implications for Esti-

mates of Price-Cost Markups

ECO No. 90/28

Stephen MARTIN

Periodic Model Changes in Oligopoly

ECO No. 90/29

Nicos CHRISTODOULAKIS/

Martin WEALE

Imperfect Competition in an Open

Economy
* * *

ECO No. 91/30

Steve ALPERN/Dennis J. SNOWER

Unemployment Through 'Learning From

Experience'

ECO No. 91/31

David M. PRESCOTT/Thanasis

STENGOS

Testing for Forecastible Nonlinear

Dependence in Weekly Gold Rates of

Return

ECO No. 91/32

Peter J. HAMMOND

Harsanyi's Utilitarian Theorem:

A Simpler Proof and Some Ethical

Connotations

ECO No. 91/33

Anthony B. ATKINSON/

John MICKLEWRIGHT

Economic Transformation in Eastern

Europe and the Distribution of Income

ECO No. 91/34

Svend ALBAEK

On Nash and Stackelberg Equilibria

when Costs are Private Information

ECO No. 91/35

Stephen MARTIN

Private and Social Incentives

to Form R \& D Joint Ventures

ECO No. 91/36

Louis PHLIPS

Manipulation of Crude Oil Futures

ECO No. 91/37

Xavier CALSAMIGLIA/Alan KIRMAN

A Unique Informationally Efficient and

Decentralized Mechanism With Fair Outcomes

ECO No. 91/38

George S. ALOGOSKOUFIS/

Thanasis STENGOS

Testing for Nonlinear Dynamics in

Historical Unemployment Series

ECO No. 91/39

Peter J. HAMMOND

The Moral Status of Profits and Other

Rewards:

A Perspective From Modern Welfare

Economics 
ECO No. 91/40

Vincent BROUSSEAU/Alan KIRMAN

The Dynamics of Learning in Mis-

Specified Models

ECO No. 91/41

Robert James WALDMANN

Assessing the Relative Sizes of Industryand Nation Specific Shocks to Output

ECO No. 91/42

Thorsten HENS/Alan KIRMAN/Louis

PHLIPS

Exchange Rates and Oligopoly

ECO No. 91/43

Peter J. HAMMOND

Consequentialist Decision Theory and

Utilitarian Ethics

ECO No. 91/44

Stephen MARTIN

Endogenous Firm Efficiency in a Cournot Principal-Agent Model

ECO No. 91/45

Svend ALBAEK

Upstream or Downstream Information Sharing?

ECO No. 91/46

Thomas H. McCURDY/

Thanasis STENGOS

A Comparison of Risk-Premium

Forecasts Implied by Parametric Versus

Nonparametric Conditional Mean

Estimators

ECO No. 91/47

Christian DUSTMANN

Temporary Migration and the Investment into Human Capital

ECO No. 91/48

Jean-Daniel GUIGOU

Should Bankruptcy Proceedings be

Initiated by a Mixed

Creditor/Shareholder?

ECO No. 91/49

Nick VRIEND

Market-Making and Decentralized Trade

ECO No. 91/50

Jeffrey L. COLES/Peter J. HAMMOND

Walrasian Equilibrium without Survival:

Existence, Efficiency, and Remedial

Policy
ECO No. 91/51

Frank CRITCHLEY/Paul MARRIOTT/ Mark SALMON

Preferred Point Geometry and Statistical Manifolds

ECO No. 91/52

Costanza TORRICELLI

The Influence of Futures on Spot Price

Volatility in a Model for a Storable

Commodity

ECO No. 91/53

Frank CRITCHLEY/Paul MARRIOTT/ Mark SALMON

Preferred Point Geometry and the Local Differential Geometry of the Kullback-

Leibler Divergence

ECO No. 91/54

Peter MØLLGAARD/

Louis PHLIPS

Oil Futures and Strategic

Stocks at Sea

ECO No. 91/55

Christian DUSTMANN/

John MICKLEWRIGHT

Benefits, Incentives and Uncertainty

ECO No. 91/56

John MICKLEWRIGHT/

Gianna GIANNELLI

Why do Women Married to Unemployed Men have Low Participation Rates?

ECO No. 91/57

John MICKLEWRIGHT

Income Support for the Unemployed in Hungary

ECO No. 91/58

Fabio CANOVA

Detrending and Business Cycle Facts

ECO No. 91/59

Fabio CANOVA/

Jane MARRINAN

Reconciling the Term Structure of

Interest Rates with the Consumption

Based ICAP Model

ECO No. 91/60

John FINGLETON

Inventory Holdings by a Monopolist Middleman 
ECO No. 92/61

Sara CONNOLLY/John

MICKLEWRIGHT/Stephen NICKELL

The Occupational Success of Young Men

Who Left School at Sixteen

ECO No. 92/62

Pier Luigi SACCO

Noise Traders Permanence in Stock

Markets: A Tâtonnement Approach.

I: Informational Dynamics for the Two-

Dimensional Case

ECO No. 92/63

Robert J. WALDMANN

Asymmetric Oligopolies

ECO No. 92/64

Robert J. WALDMANN/Stephen

C. SMITH

A Partial Solution to the Financial Risk and Perverse Response Problems of Labour-Managed Firms: Industry-

Average Performance Bonds

ECO No. 92/65

Agustín MARAVALL/Víctor GÓMEZ

Signal Extraction in ARIMA Time Series

Program SEATS

ECO No. 92/66

Luigi BRIGHI

A Note on the Demand Theory of the

Weak Axioms

ECO No. 92/67

Nikolaos GEORGANTZIS

The Effect of Mergers on Potential

Competition under Economies or

Diseconomies of Joint Production

ECO No. 92/68

Robert J. WALDMANN/

J. Bradford DE LONG

Interpreting Procyclical Productivity:

Evidence from a Cross-Nation Cross-

Industry Panel

ECO No. 92/69

Christian DUSTMANN/John

MICKLEWRIGHT

Means-Tested Unemployment Benefit

and Family Labour Supply: A Dynamic

Analysis
ECO No. 92/70

Fabio CANOVA/Bruce E. HANSEN

Are Seasonal Patterns Constant Over

Time? A Test for Seasonal Stability

ECO No. 92/71

Alessandra PELLONI

Long-Run Consequences of Finite

Exchange Rate Bubbles

ECO No. 92/72

Jane MARRINAN

The Effects of Government Spending on

Saving and Investment in an Open

Economy

ECO No. 92/73

Fabio CANOVA and Jane MARRINAN

Profits, Risk and Uncertainty in Foreign

Exchange Markets 


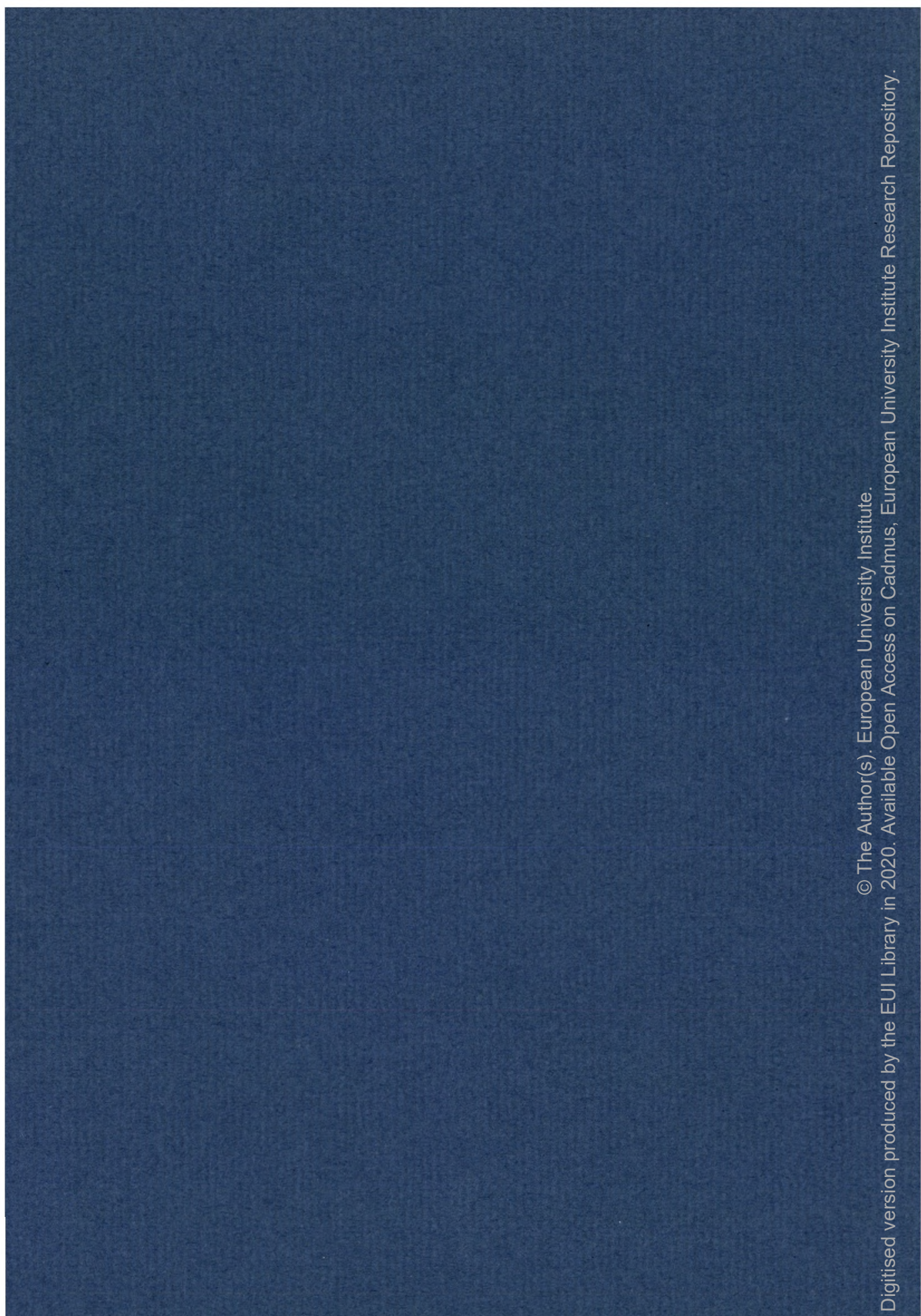


